\title{
Flavius Josephus, 1492
}

\author{
Julian Weiss ${ }^{1}$
}

Published online: 7 July 2016

(c) The Author(s) 2016. This article is published with open access at Springerlink.com

On 27 March in that extraordinary year of 1492, Alfonso de Palencia (1423-1492), the renowned royal chronicler and humanist, published his Spanish translations of two works by Josephus: the Jewish War, his eye witness account of the rebellion that led to the destruction of Jerusalem by the emperor Vespasian and his son Titus, and Against Apion, the polemical defence of Jewish belief and culture. He worked not from the original Greek, of course, but from the fourth-century Latin version attributed to Rufinus of Aquileia, a contemporary of Jerome. ${ }^{1}$ Although Palencia had completed the translations the previous year, the timing of their publication in print commands our attention. For only a few days later, on March 31, the Edict expelling the Jews from the Kingdoms of Castile and Aragon was issued in the Alhambra, the Nasrid palace of Granada now converted to Royal Christian abode. At a time when the leaders of Church and State were uprooting the Jewish people from one of their ancestral homes, Sefarad being the oldest, largest and, for centuries, the most culturally vibrant Jewish community in Western Europe, Iberia's intelligentsia were attempting to make sense of their Jewish past and its legacy.

For María Rosa Menocal, 'Spain defined itself as a modern nation through the expulsion not only of its Jewish and Muslim citizens but especially through the expulsion of the memory that they had ever been a part of the real body politic of "Spain".,2 But the historical memory was never expelled; it was managed and put to work in the figure of the Judaizer. David Nirenberg underscores the paradox that

\footnotetext{
${ }^{1}$ Guerra judaica con los libros contra Apion, Seville, 1492. For a digitized copy, see http://bdh.bne.es/ bnesearch/detalle/bdh0000176403.

${ }^{2}$ M. R. Menocal, 'Why Iberia?’, Diacritics, 36: 3-4, Fall-Winter, 2006, pp. 7-11 (7 [emphasis original]).

Julian Weiss

julian.weiss@kcl.ac.uk

$1 \quad$ King's College London, London, UK
} 
having expelled the Jews Spain appeared 'haunted by the conviction that it was becoming Jewish. ${ }^{3}$ Moreover, he continues,

these were exhilarating times for a Christian society trained to hear the hoof beats of the apocalypse in the retreating footsteps of the Jews. But they were also highly unsettling to a society used to thinking about Christianity in terms of its difference from Judaism. How would Christianity define itself if the living exemplars of that difference vanished? (p. 222)

In these 'exhilarating' and 'unsettling' times, Josephus surely matters. Recent scholarship reveals this Romanized Jewish writer's capacity to both flatter and challenge the imperial order, to move within the interstices of power, and to provide what John Barclay describes as "a perfect example of "the empire writing back"., What happens to this unsettling potential when transposed into a new imperial order, one that emulated Rome and imagined the recently conquered Kingdom of Granada as its 'new Jerusalem'? Given the historical circumstances, the lack of interest in Palencia's Josephus is surprising: indeed, the state of scholarship on Josephus in medieval and early modern Spain remains more or less where it was when Louis Feldman surveyed the field in the 1980s. ${ }^{5}$

My aim here is to speculate on the meanings that Palencia's Josephus might have had in this new Spain of 1492, as a preliminary sketch for a project on the early modern Spanish reception of Josephus. What concerns me here is the combination of the Jewish War and Against Apion rather than the works individually. In his preface, Palencia explains that, nearing seventy, he could only dream of translating the twenty books of the Antiquities: 'the old', he observed, 'are rightly cautious when it comes to undertaking long journeys' (sig. a2 ${ }^{\mathrm{v}}$ ). ${ }^{6}$ One might argue that the pairing of the Jewish War and Against Apion was predetermined by his Latin source (probably Verona, Petrus Maufer, 1480), but the combination was popular. ${ }^{7}$ Palencia's decision was calculated, and its significance is underscored by the French and Italian translations of 1492 and 1494 which ignore Against Apion. In essence, the Spanish volume puts the case for and against the Jews. For although the Jewish War is a complex and nuanced work, ultimately Josephus blames the destruction of Jerusalem on the Jewish rebels, whose sectarianism, pitiless violence and refusal to accept Roman rule lead to the city's downfall. In the Jewish War, Josephus was the Jews' most incisive critic; in Against Apion, he was their most ardent and eloquent defender.

\footnotetext{
${ }^{3}$ D. Nirenberg, Anti-Judaism: The History of a Way of Thinking, London, 2013, p. 218.

4 J. M. G. Barclay, 'The Empire Writes Back: Josephan Rhetoric in Flavian Rome', in Flavius Josephus and Flavian Rome, ed. J. Edmondson et al., Oxford, 2005, pp. 315-32 (319).

5 L. H. Feldman, Josephus and Modern Scholarship (1937-1980), Berlin, 1984, pp. 865-8. Most entries are by or about M. R. Lida de Malkiel, who died before completing her major study on Josephus in Hispanic literature.

${ }^{6}$ He died later in the year, leaving incomplete his major Latin chronicle, the Gesta hispaniensis.

7 For the identification of Palencia's source, see J. Durán Barceló, 'Alfonso de Palencia: Traductor de Flavio Josefo', in Proyección histórica de España en sus tres culturas, Castilla y León, América y el Mediterráneo, ed. E. Lorenzo Sanz, II (Lengua y literatura española e hispanoamericana), Valladolid, 1993, pp. 27-34.
} 
The only hypothesis about Palencia's intentions was advanced over twenty years ago by Javier Durán. He suggested that Palencia 'recuperated' Josephus's goals, which were, in essence, to promote the achievements of Jewish culture; in doing so, Palencia offered a timely defence of the cause of the Jewish people. ${ }^{8}$ It is unclear how Durán reconciles this pro-Jewish interpretation with what Palencia himself writes in his dedication to Queen Isabel. Remarking that Josephus displayed 'such great hatred of the cursed customs of the Jews, his contemporaries', he resorts to the traditional Christian view that Jerusalem's long-prophesied destruction was caused by a combination of 'divine indignation' and the Jews' own 'most foolish rebellion' (sig. $\mathrm{a} 2^{\mathrm{r}}$ ).

There is more to Palencia's preface than meets the eye, but for now it is enough to emphasize that the problem of how to assess his translations as an intervention in the culture and politics of his day is far more complex than a simple dichotomy between defence and condemnation. In part, this is because since Durán published his study, we have refined our understanding both of Josephus and of the events leading up to 1492 and its aftermath. But complexity also derives from the combined processes of translation and reception. There is no need to labour the point theoretically. (Borges's Pierre Menard, author of 'El Quijote, provides an eloquent parable of the multi-layered historicity of meaning, the futility of trying to recuperate past intentions, and the creative power of anachronism.) In practical terms, the difficulty is to assess the nature and effects of the various filters through which Palencia read Josephus. That mediation is historical (such as the epochmarking wave of conversions that followed the pogroms of 1391) and discursive: Ruffinus's translation, the centuries of Latin commentary and vernacular adaptations, Christian/Jewish polemic, popular legends about the destruction of Jerusalem, the chronicles of Hegesippus and Josippon, the stories woven into tapestries and engraved in woodcuts, and the emergence of a discourse of race, which prioritized bloodline over belief in determining Jewish identity. All these constitute a shifting horizon against which Palencia's translations need to be read, and this horizon is marked by discontinuity as much as by continuity of meaning and implication.

Durán described Palencia's enterprise as an act of 'recuperation'; the term is not entirely misplaced. Like his more famous fellow humanist, Antonio de Nebrija, who boasted that he had 'dispelled barbarity' from Spain, Palencia's attempts to revive the classics through translation and emulation were motivated by the belief that the recuperation of classical models would empower the present, enabling his compatriots to see, think, and write about their world afresh. Thus, rather than being a direct intervention in monarchical and ecclesiastical policy, the Josephus translations were an attempt to cut through the discursive tangle surrounding Jews by turning to the leading authority on Jewish history and identity, and by distancing himself from the vulgo, 'accustomed as it is to follow general opinion' (sig. a2 ${ }^{\mathrm{v}}$ ). To convey Josephus's auctoritas, Palencia followed what contemporaries regarded as the most authoritative method of translation, ad verbum, with parenthetical explanatory glosses, deemed superior to translations undertaken ad sententiam, a

\footnotetext{
8 Ibid., p. 28.
} 
freer style more appropriate for a readership of lesser intellects. ${ }^{9}$ To modern (and, by the 1530 s, to early modern) ears, the result often sounds rebarbative and obscure, although some passages were perhaps garbled by printers. The prose is austere, as Palencia unfolds the hypotactic syntax of his Latin source into sequences of paratactic structures linked by conjunctions. Even so, he occasionally injects fluidity and rhetorical patterning by, for example, introducing cadences with tripartite repetition.

Palencia's deferential literalism has consequences at the lexical level. A semantic study of Josephus's vocabulary as it moves from Greek to patristic Latin to late medieval Castilian is clearly needed. I have yet to undertake a systematic analysis, but one such word is 'to Judaize.' Josephus employs the verb on only a couple of occasions in Book II of the Jewish War, where it refers to non-Jews who provide material support or sympathy for Judeans during the bloody conflicts in Syria (II.461). The late Latin rendering, judaizans or 'Judaizer', slips naturally into Castilian as 'judaizante', carrying with it centuries of accumulated ideological baggage. The original term lacked the negative connotations that it would acquire since St. Paul transformed it into a keyword of anti-Jewish thought: to live and think as a Jew, according to the letter not the life-giving spirit, blindly trapped in the dead world of the flesh. In Spain, following the mass conversions of 1391, the anticonverso riots of 1449 and the establishment of the Inquisition in 1478, further meanings unfold, most notably, to be a dirty crypto-Jew. ${ }^{10}$ It is improbable that Palencia's readers (or even the translator himself) would have been able to swim against the current of time and rescue the positive connotations that the word held for Josephus. These new meanings inevitably colour the historian's narrative of the atrocities in the cities of Syria: this is a tale of slaughter and counter slaughter, mutual suspicion and fear, which pits Syrian against Jew and ensnares sympathizers on both sides. For Palencia's readers, the Syrian judaizantes would have crossed the line that distinguishes human sympathy from religious belief and bloodline.

One other instance of the modulating effects of time and cultural difference comes from the vocabulary of mob rule and civil strife. Josephus's stasis metamorphoses into the medieval Latin scandalum, which then entered the political lexicon of the Middle Ages as a term that linked political to moral disorder, particularly as a threat to sovereign power. Its vernacular form, escándalo, acquired particular resonance in Alfonso X's great thirteenth-century Roman law code, the Siete Partidas, which provided juridical underpinning for late medieval and early modern theories of monarchical absolutism. A manuscript of the code was owned by

\footnotetext{
9 Palencia's mentor, Alonso de Cartagena (see below) defended this style against the Italian humanist Pier Candido Decembrio, in heated debate over the latter's translation of Aristotle. T. González Rolán et al., Humanismo y teoría de la traduccón en España e Italia en la primera mitad del siglo XV: edición y estudio de la Controversia alphonsiana (Alfonso de Cartagena vs. L. Bruni y P. Candido Decembrio), Madrid, 2000.

${ }^{10}$ See Nirenberg, Anti-Judaism (n. 3 above), pp. 59-60, 93-134 (early Christianity), and 228-45 (XVc Spain); R. Dán, 'Judaizare-the Career of a Term', in Antitrinitarianism in the Second Half of the 16th Century, ed. R. Dán and A. Pirnát, Budapest and Leiden, 1982, pp. 25-34. On the complex range of affiliations of non-Jews to Judaism, and associated terminological problems, see L. H. Feldman, 'Jewish "Sympathizers" in Classical Literature and Inscriptions', Transactions of the American Philological Association, 81, 1950, pp. 200-08 (206-07 for Josephus).
} 
the Catholic Monarchs, and the same printers who produced Palencia's Jewish War and Against Apion in March 1492 published a copiously annotated version in October the previous year. ${ }^{11}$ It is no surprise, then, that while the medieval Latin variously labels the Judean rebels as, for example, tyranni, seditiosi or scandalosi, Palencia repeatedly returns to escandalosos. The frequent references to 'scandalous' Jewish rebels and their resistance to Roman rule would trigger, and be re-energized by, deeply rooted associations in medieval political thought between Judaism and kingship. As David Nirenberg remarks, the popular legends about Vespasian's conquest of Jerusalem and his enslavement of the Jews constituted 'the founding example of the Christian monarch's correct relationship to his Jewish subjects.' ${ }^{12}$ The term's meaning would continue to evolve in the early sixteenth century; scandalum entered the lexicon of censorship: Josephus's 'scandalous' rebels might thus epitomize the link between religious perversity and political sedition. ${ }^{13}$ However, Nirenberg also highlights the contingencies and contradictions in the ways Judaism could be pressed into ideological service as a means to both extend and resist monarchical sovereignty (pp. 183-216). It is precisely because of these ambiguities that Josephus mattered in late fifteenth-century Spain, even though we still need to examine how they influence the translation's verbal texture.

\section{The Historian and Testimony: Commitment and Alignment}

To translate Josephus is to invite into discussions and representations of Judaism a Jewish writer who came armed with a Christian calling card. He was a recognized independent witness for biblical history, eulogized by Jerome (De viris illustribus, XIII), whose stamp of approval adorns numerous manuscripts and printed editions of his works. ${ }^{14}$ By Palencia's time, he was already a familiar authority amongst vernacular lay readers, principally because of his prominence in the highly popular universal history of Alfonso X, the General estoria. This work, begun in the 1270s but still unfinished at the monarch's death in 1284, had a wide manuscript circulation in the fifteenth century, figuring in many aristocratic libraries. Josephus's Antiquities looms large in five of the six books that were completed, occupying equal footing with patristic sources, with citations often blurring the distinction between the Jewish writer and the holy fathers. However, Alfonso's team (made up, as is well known, by Jewish, Muslim and Christian men of letters) also worked critically, reconciling Josephus's testimony with biblical accounts, signalling

\footnotetext{
11 See Diccionario filológico de la literatura medieval española: textos y transmisión, ed. C. Alvar and J. M. Lucía Megías, Madrid, 2002, pp. 19, 26-7.

12 Anti-Judaism (n. 3 above), p. 187.

13 M. J. Vega, 'Escandaloso, ofensivo y malsonante. Censura y vigilancia de la prosa espiritual en la España del Siglo de Oro', Criticón, 120-121, 2014, pp. 137-54 (145-7).

14 Jerome expresses wonderment at Josephus's Greek learning in Epistle 70; for Palencia's translation see sig. $z 9^{\mathrm{v}}$.
} 
differences, or citing him to rebut ancient calumnies against Moses and the Jews. ${ }^{15}$ By 1492, Palencia's praise of the Antiquities, that 'solemn compendium of true and approved history' (sig. a2 ${ }^{\mathrm{v}}$ ), would have had a ring of familiarity. Besides the Catalan translation printed in 1482 for an urban readership (see below), Josephus's prestige in aristocratic circles is attested by the luxury manuscripts of the Latin Antiquities and Jewish War produced for noble bibliophiles. ${ }^{16}$

Palencia does not mention competing accounts of Jewish history available at the time. Some were by Josephus's avatars: the fourth-century Jewish convert to Christianity known as Hegesippus and Josippon, or Joseph ben Gorion from tenthcentury Italy, whose Hebrew chronicle was attributed to Josephus well into the early modern period. In his De excidio Hierosolymitano, Hegesippus claimed that while Josephus wept over the destruction of Jerusalem, he 'did not understand its cause.' ${ }^{17}$ The work draws heavily on Josephus and had a wide readership, being reprinted in various forms throughout the sixteenth century; a luxury manuscript copy is in the library of the Dukes of Osuna. ${ }^{18}$ Josippon (editio princeps: Mantua, 1476) was also widely read by Jews and Christians alike and a partial Castilian translation (c. 1461-1480) witnesses late medieval Iberian interest. The extract focuses on events related to Jerusalem and its Temple, 'destroyed for the third time as a result of the sins of the people of Israel', thus betraying, perhaps, the influence of the popular legends that circulated throughout Europe which interpreted Vespasian's destruction of Jerusalem as an act of divine retribution. ${ }^{19}$ Although most legends derive from the twelfth-century French poem La Vengeance Nostre Seigneur, certain elements are borrowed from Josephus, and their popularity in Catalan, Portuguese and Castilian is well attested, with several printings from the $1490 \mathrm{~s}^{20}$

\footnotetext{
15 M. R. Lida de Malkiel, 'Josefo en la General Estoria', in Hispanic Studies in Honour of I. González Llubera', ed. F. Pierce, Oxford, 1959, pp. 163-81 (181). For the General estoria, see Diccionario filológico (n. 11 above), pp. 42-54.

16 Madrid, Biblioteca Nacional de España, MSS 10270 and Res. 216; J. Domínguez Bordona, Manuscritos con pinturas: notas para un inventario de los conservados en colecciones públicas y particulares de España, I, Madrid, 1933, pp. 300 and 343, nos 748 and 878; see also the Hegesippus mentioned below. The Antiquities also provided a model for Palencia's unfinished Antiquitatum Hispaniae Gentis (Antiquities of the Spanish People).

17 A. A. Bell, Jr., 'Josephus and Pseudo-Hegesippus', in Josephus, Judaism, and Christianity, ed. L. H. Feldman and G. Hata, Leiden, 1987, pp. 349-61 (352).

18 Madrid, Biblioteca Nacional de España, MS 10.189; Domínguez Bordona, Manuscritos, I (n. 16 above), p. 300, no. 739 .

19 Cited from M. Sueiro Pena, 'Las dos lecturas de Josefo en la España medieval: la Guerra judaica de Alfonso de Palencia y el Yosifón en romance', in Actas del VIII Congreso Internacional de la Asociación Hispánica de Literatura Medieval (Santander 22-26 de septiembre de 1999), ed. M. Freixas and S. Iriso, II, Barcelona, 2000, pp. 1677-91 (1682). For the manuscript see G. Avenoza, 'Datos sobre el códice M-54 de la Biblioteca de Menéndez Pelayo de Santander: el Yosifón en romance', Boletín de la Biblioteca Menéndez Pelayo, 75, 1999, pp. 393-401.

20 Destructión de Jerusalem: Historia del noble Vespasiano, Toledo, Juan Vázquez, 1491-1494; repr. Seville, Peter Brun, 1499; Portuguese version, Lisbon, Valentim Fernandes, 1496. See D. Hook, ed., The Destruction of Jerusalem: Catalan and Castilian Texts, London, 2000. For Lida de Malkiel's survey of the topic, with numerous references to Josephus (though not to Palencia's translation), see Jerusalén: el tema literario de su cerco y destrucción por los romanos, Buenos Aires, 1972 [1943].
} 
On this bibliographical horizon, Josephus would have surely figured, at least for the Spanish humanist, as the most authoritative source for the fall of Jerusalem and, via Against Apion, for knowledge about Jewish antiquity, belief and tradition. For medieval and early modern readers, who by habit signalled memorable facts or gobbets of moral wisdom in the margins of their copies or gathered them in commonplace books, knowledge is key. Josephus's history, Palencia announced, is replete 'with ornate style, authority, sentences, and beneficial doctrine' ('de ornato, e de auctoridad, e de sentencias, e de provechosa doctrina'; sig. a $3^{r}$ ). The first term, ornato, should not be dismissed as mere ornamentation. Though unobtrusive, it points to another fundamental reason why Josephus needed to be translated at this historical juncture. To be aware of his style, how he situates his readers rhetorically, is to recognize his ideological potential for late medieval and early modern thinking about the historian's relationship to power.

Tessa Rajak, amongst others, emphasizes how Josephus makes us reflect upon the contingency of historical writing - how it is shaped by calamity, exile, cultural dislocation as well as by the tension between the author's political alignments and his cultural affiliations. In large measure, this is because he so often foregrounds the value of his own testimony as eye witness and protagonist in events. Within the tragic spectacle of the Romans' destruction of the Second Temple, there is the spectacle of Josephus himself, failed general, Roman captive, railing ineffectually against self-defeating Jewish sectarianism and obstinate resistance to Imperial rule. $^{21}$ As an intermediary, he stands both inside and outside of Judaism and, so to speak, both inside and outside of history.

Josephus thus acquires special relevance for the historiographical debates of late medieval Spain. The way he positions himself and, equally importantly, the way he himself is positioned by personal and historical circumstance resonates with themes that run throughout fifteenth-century Spanish discussions of the historian's craft and responsibilities. Writers like Fernán Pérez de Guzmán (d. 1460), author of the political biographies Generaciones y semblanzas, insisted that the historian served truth over partisan interest, which could be achieved only by narrating events from a safe temporal distance. Josephus thus epitomizes a paradox: here is a writer whose authority derives from being an eye witness, an active participant in historically specific events; even as he writes from within, he strives to transcend his circumstances and his obligations to his Roman masters. Operating close to the centre of power, he preserves a measure of distance from it. This is not to ignore his self-serving justifications or his flattery of his patrons. It is to acknowledge that Josephus invites us to adopt an ironic perspective, to read between the lines of his writing and trace how he himself moved between lines, or, as Tessa Rajak puts it, 'between local patriotism and the claims of the imperial order, between native culture and the allure of Greco-Roman civilisation..., between pragmatic flexibility and committed sectarianism. ${ }^{22}$

\footnotetext{
21 See T. Rajak, Josephus: The Historian and His Society, London, 1983, pp. 4 and 6; H. Howell Chapman, 'Spectacle in Josephus' Jewish War', in Flavius Josephus and Flavian Rome, ed. Edmondson et al. (n. 4 above), pp. 289-313 (293-6).

22 Josephus, p. 1. See also Barclay, 'The Empire Writes Back' and two essays by S. Mason, 'Figured Speech and Irony in T. Flavius Josephus', in Flavius Josephus and Flavian Rome, ed. Edmondson et al.
} 
In principle, though not in degree, these tensions also animate Palencia's chronicle of recent Spanish conflicts in which he himself was an active eye witness. His Gesta Hispaniensia, which lay unfinished and in manuscript on his death, covered the reign of Henry IV to the early years of the reigns of the Catholic Monarchs (1454-1481), a period racked by factionalism, civil war, growing religious intolerance, and threats to monarchical sovereignty. Palencia balanced support for the monarchy while challenging the perceived excesses of power, tempering his advocacy of the Aragonese Ferdinand with recognition of his weaknesses, such as his tendency to give into the wishes of Isabel and her coterie. Indeed, during his political career, Palencia, like Josephus, switched sides, first supporting Isabel's opponents in the civil war that brought her to power, then, in 1468, changing his allegiance when he realized that the tide was turning. In 1456, he was appointed royal chronicler and Latin secretary to Henry IV (whom he later pilloried), but by the 1480s he had lost the trust of Isabel, who turned to other chroniclers, such as Fernando de Pulgar, to record more favourable versions of events.

Palencia's concept and practice of history owe much to classical models and civic humanists, particularly Livy and George Trebizond, his favourite teacher. ${ }^{23}$ Josephus thus joins historians such as Livy, Sallust and Plutarch (whom Palencia also translated: Parallel Lives were printed in 1491) as a model of historiographical practice. From them, he learned that the historian should explain, not simply relate, significant events and that structural flexibility, digressions and personal interventions allowed for the analysis of cause and effect without the chronological constraints of the annalistic method. Like Josephus, Palencia mustered documentary evidence as well as such rhetorical resources as direct and indirect speech and truth claims; like Josephus, he strove to bring the past to life and, through the visual aesthetics of enargeia, to set it before the reader's eyes, 'ut rhetorica pictura., ${ }^{24}$ Tellingly, his Latin-Spanish glossary, Universal vocabulario (1490), defines 'history' by the Greek etymology historin: 'quod est videre vel cognoscere. Apud veteres enim nemo scribebat historiam nisi is qui interfuisset. ${ }^{25}$ History is personal, both because it recreates the vision of those who witnessed and participated in past events, and because it forges a psychological and affective bond between them and the modern reader.

\section{Footnote 22 continued}

(n. 4 above), pp. 244-88; 'Flavius Josephus in Flavian Rome: Reading On and Between the Lines', in Flavian Rome: Culture, Image, Text, ed. A. J. Boyle and W. J. Dominik, Leiden, 2003, pp. 559-89.

23 See R. B. Tate, 'Alfonso de Palencia y los preceptos de la historiografía', in Nebrija y la introducción del Renacimiento en España, ed. V. García de la Concha, Salamanca, 1996, pp. 37-52; Gesta Hispaniensia ex annalibus suorum dierum collecta, ed. B.Tate and J. Lawrance, 2 vols., Madrid, Real Academia de la Historia, 1998-1999, pp. 1xi-lxiii. For the classical models available in the vernacular, see A. Coroleu, 'A Preliminary Survey of Greek and Latin Historians in Translation in the Iberian Peninsula (c. 1360-1599)’, Bulletin of Spanish Studies, 81, 2004, pp. 897-912.

24 Tate, 'Alfonso de Palencia' (n. 23 above), p. 50.

25 Universal vocabulario en latín y en romance, s.v. historia, cited in Real Academia Española: Banco de datos (CORDE) [online]. Corpus diacrónico del español. http://www.rae.es [consulted 30.03.2015]. 
By the 1490s, the poetics of presence had become established in Castilian letters. The most vivid example was the epic Laberinto de Fortuna (1444), by Palencia's immediate predecessor as royal chronicler and Latin secretary, Juan de Mena. In his mammoth commentary (1499, revised 1505, and a Renaissance best-seller), the humanist Hernán Núñez praised Mena's ability to make the reader experience the events narrated, most powerfully in a scene that depicts a mother's lament over the death of her warrior son, killed in a noble but futile enterprise. Although an unashamedly propagandistic poem, it also registers at the level of the affect the possibility to adopt multiple perspectives and to experience the vision of the vanquished. The political and historical ironies of the poem are brought out in Núñez's commentary, as he encourages his readers to contemplate the action as if they were spectators in an amphitheatre, critically detached yet emotionally involved. $^{26}$

For Palencia and his contemporaries, therefore, history provides knowledge and experience. It is a way of seeing (videre) and of knowing (cognoscere). Although they are not coterminous, they overlap in a space that might be called 'experiential knowledge', which fosters critical perspectives, independent judgement and, potentially, dissent. In the preface to his Castilian translation of the Ilias latina (c. 1440, printed 1519), Juan de Mena acknowledged that our experience of Priam's death throes, the grief for Hector, and Paris's desire, is purely a rhetorical effect. Implicitly, he asks us to reflect upon how our understanding of the past is coloured by rhetorically fabricated emotions. ${ }^{27}$ Ideas such as these would have reanimated Josephus's preface to the Jewish War. For here, even as he insists on the veracity and balance of his account, Josephus calls attention to the shaping influence of his own emotional attachments and he asks his readers (in Palencia's phrasing) to 'attribute the deeds to history and the lamentations to the writer' (sig. $a 4^{r}$ ). The disjunction between recorded event and emotional response is symptomatic of what Raymond Williams described as the tension between commitment and alignment. The writer's freedom is inevitably determined by factors over which he has no control. However much we strive to align ourselves with a cause, we are also constrained by pre-existing alignments - inherited language, patronage, historical circumstance - and true commitment means acquiring 'active consciousness of ourselves and our practices... speaking for oneself, and through this, for others.' 28 Palencia's awareness of the tension between the local demands of patronage and the moral obligation to a higher truth imbues his historical writings and his epistles; his politically independent stance, or pose, is generally attributed to the influence of Livy. ${ }^{29}$ Towards the end of his life, Josephus was doubtless equally important as a

\footnotetext{
${ }^{26}$ Hernán Núñez de Toledo, Glosa sobre las 'Trezientas' del famoso poeta Juan de Mena, ed. J. Weiss and A. Cortijo Ocaña, Madrid, 2015, pp. 90-92, 126-45, 1056-7.

27 See J. Weiss, The Poet's Art: Literary Theory in Castile, c. 1400-60, Oxford, 1990, pp. 78-9.

28 R. Williams, 'The Writer: Commitment and Alignment', in Resources of Hope: Culture, Democracy, Socialism, ed. R. Gable, London, 1989, pp. 77-87. See also E. W. Said, Representations of the Intellectual: The 1993 Reith Lectures, London, 1994, pp. 3-17. I explore these issues in relation to medieval clerics - Palencia's forebears - in The 'Mester de Clerecía': Intellectuals and Ideologies in Thirteenth-Century Castile, Woodbridge, 2006.

29 Tate, 'Alfonso de Palencia' (n. 23 above), pp. 40-41, 45.
} 
case study in the contingency of historical writing and the value of testimony in shaping attitudes towards the past, in and for the present.

\section{'Convivencia': Readerly Co-existence}

Thematically, there are obvious reasons why Josephus's Jewish War would appeal to Isabel. In his dedication, Palencia harnesses for his own ends the Jewish historian's admiration for Roman military might, strategy and conduct, declaring that Isabel will delight in reading about the conduct of the war. He then eulogizes her leadership of the Granada campaign, which led to the expulsion 'of Mohammed's cursed name from such a noble part of your domains' (sig. a2 ${ }^{\mathrm{v}}$ ) and the cleansing of the Granadan mosques of 'spurcicias mahométicas' ('Mahommedan dirt'; sig. a $3^{\mathrm{r}}$ ). ${ }^{30}$ Following the capitulation, the former Nasrid city was called 'the New Jerusalem', to commemorate a resurgent Christianity backed by crusading force of arms, while Catholic Spain became the new Rome. ${ }^{31}$ A few months after the publication of Palencia's Josephus, Antonio de Nebrija prefaced his Gramática castellana - the first vernacular treatise of its kind in Europe - by reworking Lorenzo Valla's thesis that language was the companion to empire. To illustrate how languages and empires rise and fall in tandem, he begins with the example of the Jews and Hebrew, which (he claims) has now decayed to such an extent that 'of all Jews who are alive today, none can explain the language of their law, any more than they can account for the loss of their kingdom, or the Messiah for whom they wait in vain. ${ }^{32}$ Although he follows with the examples of Greek and Latin, Hebrew provides the most powerful motivation to reduce Castilian, now at the peak of perfection, to grammatical rule in order to combat the corrosion of time.

Josephus's thesis that the Jews would be best served by living under the protection of Imperial Rome also lent classical authority, if such were needed, to the well-established medieval notion of the Jews as servi camerae. Other themes in the Jewish War would have struck a chord with the Catholic Monarchs as they reflected upon their rise to power: Josephus's flattering marriage of imperial might and clemency; his depiction of Judean factionalism, brigandage and tyrannical sedition; his insight into the conduct and psychology of urban mobs. Josephus's fondness for metaphors of contagion to describe the spread of political unrest meld effortlessly

\footnotetext{
${ }^{30}$ A calque of spurcicia mahometici, from the consecration rituals of former mosques; see A. G. Remensnyder, 'The Colonization of Sacred Architecture: The Virgin Mary, Mosques, and Temples in Medieval Spain and Early Sixteenth-Century Mexico', in Monks and Nuns, Saints and Outcasts: Religion in Medieval Society, ed. S. Farmer and B. H. Rosenwein, Ithaca, 2000, pp. 189-219 (194).

31 See M. García-Arenal, 'Granada as a "New Jerusalem": The Conversion of a City', in Space and Conversion in Global Perspective, ed. G. Marcocci et al., Leiden, 2014, pp. 15-43. On the desire of the late 15th and early 16th-century Spanish and Portuguese monarchies to recover Jerusalem, see Hook, The Destruction of Jerusalem (n. 20 above), pp. 122-3. For the obsession with replicating the sacred topography of Jerusalem, including the late 16th-century fantasy that the Toledan landscape exactly matched that of the Holy City, see A. Beaver, 'From Jerusalem to Toledo: Replica, Landscape, and the Nation in Renaissance Iberia', Past \& Present, 218, 2013, pp. 55-90.

32 Gramática sobre la lengua castellana, ed. C. Lozano, Madrid, 2011, p. 5.
} 
with the Edict of Expulsion, which represents the Jew as a polluting presence, contaminating New Christians and undermining the integrity of the body politic.

Palencia makes no mention of the impending expulsion of the Jews. As he explains, he had completed his translation in 1491 and although the preface's precise date cannot be ascertained, the apparent suddenness of the decision to expel the Jews makes it unlikely that he translated Josephus with such a specific policy in mind. ${ }^{33}$ Nor does he allude to the drive to convert and baptize Jews, which is such an important ideological feature of the legends of the destruction of Jerusalem circulating in late medieval Iberian religious drama and prose, as David Hook has shown. ${ }^{34}$ Although one can search for parallels and lessons, Josephus's political significance needs to be broadly construed. For the late fifteenth century, the real political crux is Josephus's conception of the Jewish polity. Although the Jewish War represents the utter annihilation of Jerusalem and the second Temple, Josephus shows an acute awareness of the enduring condition of Judaism as a politeia, 'a constitution in the broadest sense ... a certain moral and social cohesion of Jewish communities within the non-Jewish civic structures surrounding them. ${ }^{35}$ The idea surfaces in the Antiquities (IV.194; 302-4), but comes to the fore in Against Apion (e.g., II. 280-96), where the Jewish constitution 'is held out for inspection as a realized Utopia, available for emulation by the rest of humanity' (p. 222). Palencia eulogizes his Jewish counterpart as a man with an unsurpassed allegiance to his patria: 'no one could be found at that time who defended his patria more valiantly, and opposed those who coloured tyranny with the name of liberty' ( $\operatorname{sig} . \mathrm{a} 2^{\mathrm{r}}$ ). The conventional phrasing, which sets liberty, truth and patria in opposition to tyranny and lies, begs an important question. Which patria is Palencia referring to? The immediate context of the passage (a summary of the Jewish War) suggests the imperial order of Rome, the protector of Jews betrayed from within by tyrannical zealots; the broader context, the pairing of the Jewish War and Against Apion, suggests the Jewish polity, a set of practices and beliefs that bind people together in allegiance to a suprapolitical community. Thus, Against Apion could be adduced in support of a concept that by the 1490s was under threat: the monarchical state as a polity composed of multiple nationes (Alfonso $\mathrm{X}$ famously described himself as 'King of the Three Religions'). When religion and ethnic identity are pressed into service of an ideological fantasy - the recovery of the lost unity of Visigothic Hispania - Against Apion acquires a threatening edge.

Meanings, political or otherwise, are not of course inherent in a text but made; to be made, they need readers. Thinking of Palencia's readership in an age of divisiveness tempts us to imagine his audience in binary terms, Jewish and

\footnotetext{
33 The bibliography on the expulsion is vast. See N. Roth, Conversos, Inquisition, and the Expulsion of the Jews from Spain, Madison, 1995; J. Pérez, History of a Tragedy: The Expulsion of the Jews from Spain, translated from the Spanish by Lysa Hochroth, introduction by Helen Nader, Urbana, 2007 ; B. Netanyahu, The Origins of the Inquisition in Fifteenth Century Spain, 2nd edn, New York, 2001.

34 See his The Destruction of Jerusalem (n. 20 above), pp. 119-20, 123-4, and 'The Legend of the Flavian Destruction of Jerusalem in Late Fifteenth-Century Spain and Portugal', Bulletin of Hispanic Studies, 65, 1988, pp. 113-28.

35 T. Rajak, 'The Against Apion and the Continuities in Josephus's Political Thought', in Understanding Josephus: Seven Perspectives, ed. S. Mason, Sheffield, 1998, pp. 222-46 (228).
} 
Christian, with two corresponding modes of reading. For Christians seeking to define themselves against Jews, even Against Apion furnished ample material to shore up the allegedly vanishing difference between them. This rich and complex defence marshals a dazzling array of arguments and auctoritates: 'a reader of the Contra Apionem can easily become entangled in the morass of ancient authors who populate its pages, confused by the to and fro of citation and refutation, and unnerved by the alternation between invective and adulation. ${ }^{36}$ Even so, this very copia enabled Josephus to conjure pro-Jewish arguments even out of the diatribes of his antagonists. ${ }^{37}$ The colophon to Palencia's translation acknowledges Josephus's rhetorical mastery: 'Here end Josephus's two books against Apion the grammarian and other Greek philosophers, whom he knew how to confute in such a way as to render worthless all their false arguments' $\left(\right.$ sig. $\left.\mathrm{z}^{1} 0^{\mathrm{r}}\right)$. If Josephus appropriated antiJewish arguments and turned them on their head, his late medieval Christian readers (at least those of an intolerant bent) could simply re-invert them: Jewish stubbornness, intolerance and misanthropy, they descended from lepers, made no contribution to civilization, their comical and sinister rituals, including kidnapping Greeks for slaughter. Refuting such slanders, Josephus keeps them alive, reenergizing medieval stereotypes and 'Blood Libel' fantasies. For the inquisitorial reader, on the lookout for Judaizers, Against Apion provided more substantial evidence of Jewish identity than a predilection for aubergines or refraining from work on Saturday.

Palencia conceived his translations when it was still possible to live in Spain as a Jew, so how might Sephardic Jews have responded to a writer whose works, as Heinz Schreckenberg pointed out, had become 'a handbook of apologetic for ancient Christianity'? For Schreckenberg, his appropriation by Christians 'may have contributed to the obscurity of this Jewish historian and theologian among his own people... Judaism lost sight of him; but neither did it need him to hold its own in the face of expanding Christianity. ${ }^{38}$ Palencia may have moved Josephus back into their line of sight, and, at a critical historical juncture, enriched their understanding about a defining moment in Jewish history and what it meant (and means) to live in exile, striving to preserve cultural identity and tradition. The vernacular Josephus can be viewed against the backdrop of the revival of Sephardic letters occurring between the 1391 pogroms and the 1492 expulsion. While this period may seem to be a mere hiatus between the earlier 'Golden Ages' and the Jewish diaspora, there are signs, amidst increasing persecution, of a critical engagement with, and a

\footnotetext{
36 J. R. Levison and J. Ross Wagner, 'Introduction: The Character and Context of Josephus' Contra Apionem', in Josephus' 'Contra Apionem': Studies in its Character and Context with a Latin Concordance to the Portion Missing in Greek, ed. L. H. Feldman and J. R. Levison, Leiden, 1996, pp. 1-48 (1).

37 L. H. Feldman, 'Reading Between the Lines: Appreciation of Judaism in Anti-Jewish Writers Cited in Contra Apionem', in Josephus' 'Contra Apionem', ed. L. H. Feldman and J. R. Levison, pp. 250-70.

38 'Josephus in Early Christian Literature and Medieval Christian Art', in H. Schreckenberg and K. Schubert, Jewish Historiography and Iconography in Early and Medieval Christianity, trans. Paul A. Cathey, Assen, 1991, pp. 1-138 (135).
} 
creative openness towards, the Christian host culture. ${ }^{39}$ Examples include the antiChristian polemics of Profiat Duran (c. 1350-c. 1415) and Hasdai Crescas (1340-1411), which created fertile conditions for an appreciative Jewish readership of the artful rhetoric and sardonic tone of Against Apion and its ridicule of Judaism's opponents. Josephus's tale of mass suicide at Masada and of Jews murdering their families to avoid enslavement and betrayal of their ancestral faith would have resonated with fifteenth-century Spanish Jews and converts. Crescas and Duran engaged in bitter debate over the choice between death and conversion. Crescas demanded martyrdom, while Duran (who himself converted to escape persecution) cited Isaiah 8:15 and argued for the redemption of those who converted, 'broken, trapped, and taken captive'. ${ }^{40}$

The Catalan translation of the Antiquities appeared in Barcelona in 1482. Its publication was co-sponsored by a local notary, Andreu Mir, and the converso bookseller Johan ça-Coma, who submitted the volume to be 'corrected' by the Franciscan Friar and professor of theology Pere Lopis. ${ }^{41}$ Jaume Riera i Sans suggests this correction was a form of censorship, which entailed moralizing or adapting passages that might offend resurgent Christianity. While he observes that the book had a ready-made audience amongst the conversos in Barcelona (p. 196), he says nothing about that city's large Jewish community or its role as a thriving centre of Jewish culture. We can take at face value Palencia's reason for not translating the Antiquities (his age), but the Catalan version may also have influenced him: we should not overstate the boundaries separating Catalan from Castilian readers. Similarly, we should not overstate those between Christian and Jew, separate but not hermetically sealed off from each other. However 'corrected' the Catalan translation was (the matter has yet to be analysed in detail), it was still available to be reclaimed by any Jew willing and able to read through the theologian's Christianizing veneer. ${ }^{42}$ By the late fifteenth century, both faiths would have found much to inspire and challenge them. Take, for example, Josephus's remarkable plea for tolerance between peoples of different beliefs and customs (XVI.174-8). Declaring his wish to reconcile nations, he argues that what makes a minority group, such as the Jews, appear alien and foreign is not religious difference but irrationality, dogmatism and hatred on all sides. While the fate of the minority lies in the hands of the ruling power, he adduces many instances of peaceful and adaptable co-existence: 'for there can be no people whose customs are always the same and there can be great differences among cities' (XVI.176). ${ }^{43}$

\footnotetext{
39 See E. Lawee, 'Sephardic Intellectuals: Challenges and Creativity (1391-1492)', The Jew in Medieval Iberia, ed. J. Ray, Boston, 2012, pp. 350-91.

${ }^{40}$ M. Saperstein, 'A Sermon on the Akedah from the Generation of the Expulsion and its Implications for 1391', in Exile and Diaspora: Studies in the History of the Jewish People Presented to Professor Haim Beinart, ed. A. Mirsky et al., Jerusalem and Madrid, 1991, pp. 103-24 (112-13).

41 See J. Riera i Sans, 'Presència de Josefus a les lletres catalanes medievals', in Studia in honorem Prof. M. de Riquer, II, Barcelona, 1987, pp. 179-220 (197-8).

42 In the early 17th century, the chuetas (crypto-Jews) of Mallorca were accused of reading the Antiquities, prohibited in the Spanish index of prohibited books of 1584. See Á. Selke, 'Flavius Josephus Among the "Chuetas" of Mallorca', Romance Philology, 28, 1974, pp. 34-5.

43 See Rajak, 'Josephus in the Diaspora', pp. 92-3. She finds this vision 'hard to parallel in ancient literature' and 'a one-off statement in Josephus.'
} 
The vernacular Josephus encourages us to deconstruct the binary opposition between Jewish and Christian readers. By this I do not mean that we should simply add a third element, the conversos, reconstituting the readership as a triad, whose three elements are each rooted in distinct group identities with clearly definable interests. Even so, it would be perverse not to reflect upon the massive and socially transformative wave of conversions inspired by the pogroms of 1391. Palencia was educated in the household of the great Alonso de Cartagena (1384-1456), who as a child converted to Christianity just before the virulent outburst of Jew hatred. His father, Pablo de Santa María, was chief Rabbi of Burgos, and on his conversion he became bishop of that city, a post that Alonso himself would eventually occupy. The Santa María clan moved easily in the upper echelons of the Castilian ecclesiastical and political elite, and Alonso, noted diplomat, humanist and intimate of King John II, was well placed to counter the converso hatred whipped up during the antimonarchical riots in Toledo 1449. His Defensorium unitatis Christianae articulated a 'converso theology', refuting the libel that the converts' Jewish blood precluded them from assuming true Christian identity. Against this racialist argument, Cartagena reasoned that New Christians, witnesses to both Old and New Covenants, were superior to those Old Christians who, little more than pagans, denied the validity of conversion based on persuasion and faith, which recognized the bond between Judaism and Christianity. ${ }^{44}$ Without calling into question the sincerity of their belief, recent scholars have shown how some conversos, like Profiat Duran, continued to 'accommodate their own Jewishness in their converted selves' and to reconcile 'the Christian faith with their self-sense of Jewishness." 45 From this perspective, Judaism needs to be understood historically, not demonized; Josephus provided such an understanding.

Spatial metaphors can be limiting, but it may be more profitable to consider how the Castilian Josephus moves along an interpretative continuum symptomatic of the porous boundaries between Christian and Jew. Perhaps one might usefully appropriate Brian Stock's concept of textual community, developed to explain the emergence and cohesion of 'small, isolated, heretical and reformist groups in medieval Europe.' Stock describes how, at the level of microsociology, collective identities are forged through shared texts and common interpretations, binding groups of listeners or readers together in ways that "can supersede the differing economic and social backgrounds of the participants, welding them, for a time at least, into a unit... . Among the members, solidarity prevails, with the outside, separation. ${ }^{46}$ At the risk of overextending the concept, the cultural conditions of medieval Iberia invite us to consider how textual communities might be welded together not only by consensual interpretation, but also by an awareness of the fluid and contentious relations between groups that share overlapping histories.

\footnotetext{
${ }^{44}$ B. Rosenstock, New Men: 'Conversos', Christian Theology, and Society in Fifteenth-century Castile, London, 2002.

45 Y. Yisraeli, 'Constructing and Undermining Converso Jewishness: Profiat Duran and Pablo de Santa María', in Religious Conversion: History, Experience and Meaning, ed. I. Katznelson and M. Rubin, Farnham, 2014, pp. 185-215.

46 Listening for the Text: On the Uses of the Past, Baltimore, 1990, pp. 150-51.
} 
To understand Iberian convivencia, Jonathan Ray argues that we need to go 'beyond tolerance and persecution'. Ray shares Stock's interest in microsociology; for him, understanding co-existence means examining how particular Jews strategically exploited the economic and social opportunities offered by Christian society:

Rather than continue to discuss this society in terms of religious communities, it might be more profitable to view it as a product of a variety of contending identities and social, cultural, and religious tensions that existed between the individual and a number of possible groups. ${ }^{47}$

Ray focuses on the thirteenth and fourteenth centuries, not the final decades of the fifteenth, with its morbid fear of a separate ethnic and religious group threatening to pollute the integrity of the Christian body politic. Yet his comments are highly pertinent to Palencia's coupling of texts that together create a terrain where competing readings of Judaism could still co-exist.

Josephus thus joins a cluster of other texts, which, though originating in different places and times, converge in their fifteenth-century literary reception to create common, albeit disputed, ground between faith groups. The following are a representative sample. Maimonides's Guide to the Perplexed entered, in Castilian translation, the magnificent library of Íñigo López de Mendoza, marquis of Santillana (1398-1458). The manuscript bears the physical traces of the contradictions within convivencia, for the translator's glosses compete with those of a later reader, whose antipathy towards Judaism is patent. ${ }^{48}$ Santillana was also thoroughly familiar with the Proverbios morales by Santob de Carrión (Rabbi Sem Tob ibn Ardutiel). Santob wrote in both Castilian and Hebrew and his proverbs (1355-1360) display 'the consciousness of a Jew in exile [writing] in a form acceptable to his host culture' - a very Josephan condition. ${ }^{49}$ Santillana's survey of Castilian verse, the Prohemio $e$ carta (1449), records one of Santob's defining statements: 'For being born on the thornbush, the rose is certainly not worth less...; nor are good proverbs, if spoken by a Jew' (p. 20). This is a poignant quotation in the year that saw the first statutes of blood purity. Whether 'Jewish wisdom' could cross the frontiers of faith soon became an open question: one textual witness derives from the inquisitorial record of an alleged Judaizer. Surviving manuscripts show Santob's proverbs to be highly adaptable; equally adaptable across faith lines were another form of wisdom literature, exempla. The collection of animal fables Calila e Dimna passed from Sanskrit, Persian, Arabic, and then, during the thirteenth century, into Castilian (for Alfonso X) and Hebrew (twice); from Hebrew it was reworked into Latin by the converted Jew John of Capua, whose version then enriched the narrative stock of late medieval and early modern

\footnotetext{
47 J. Ray, 'Beyond Tolerance and Persecution: Reassessing Our Approach to Medieval Convivencia', Jewish Social Studies, 11: 2, Winter, 2005, pp. 1-18 (13). Ray's approach is similar to that of Brian Catlos, who explores the 'principle of convenience' (conveniencia) governing interfaith relations in medieval Iberia: see, e.g. Muslims of Medieval Latin Christendom, c. 1050-1614, Cambridge, 2014.

48 Maimonides' Guide for the Perplexed: A 15th Century Spanish Translation by Pedro De Toledo (Ms. 10289, B.N. Madrid), ed. M. Lazar and R. Dilligan, Culver City, 1989.

49 T. Perry, The 'Moral Proverbs' of Santob de Carrión: Jewish Wisdom in Christian Spain, Princeton, 1987, p. 165.
} 
Europe. One fifteenth-century Castilian version, bypassing Alfonso X's Arabic source, returned to the Hebrew rhymed prose of Jacob ben Eleazar (1170-1233?). Castilian printings of 1493 and 1498 and the manuscript owned and annotated by Queen Isabel testify to the book's transcultural currency in late medieval Spain. Finally, one cannot forget the medieval vernacular Spanish Bibles, which, in the case of the extraordinary Biblia de Alba (1422-1430), commissioned by the Grand Master of Calatrava from Moshe Arragel de Guadalajara, are testimony to the tense cooperation between Christian and Jewish translators and exegetes, or the most enduring example of literary convivencia, the oral ballad (romancero). For centuries, the same poetic narratives, reworked according to time, place and audience, provided Jew and Christian alike with a cultural memory of their shared past.

In this context, the printing history of Palencia's translation is eloquent. In 1532, Jacob Cromberger revised the Jewish War in light of a recently improved Latin edition, amending the Spanish to eliminate archaisms and other perceived infelicities. ${ }^{50}$ While retaining the original's folio format, Cromberger facilitates the reader's passage through the text by adding new chapter divisions, summaries of the content, and a detailed table of contents (fols $133^{\mathrm{v}}-36^{\mathrm{r}}$ ). These changes are conditioned by new attitudes towards translation and by developments in the materiality of the printed book, which in turn are shaped by the twin need to foster and to guide the interpretative autonomy of a wide reading public. While Cromberger enables the reader to move around the text, read selectively and locate passages of personal interest, he closes down interpretative freedom by eliminating Against Apion, Palencia's companion piece to the Jewish War.

Cromberger was an industrious and commercially cautious printer; he removes Against Apion because 'it is a separate work, whose subject ['materia'] does not deal with, and is not relevant to, the history of these seven books' (fol. 133 ${ }^{\mathrm{v}}$ ). Although Josephus intended Against Apion as a companion piece to the Antiquities, rather than to the Jewish War, Cromberger's decision is disingenuous. Instead of a volume that presents - to put it crudely - the case against and then for the Jews, he produced one that served solely as a witness to the destruction of Jerusalem, brought about by Jewish sectarianism and resistance to Empire. The new subtitle devised for this revised edition is telling: la destruyción de Jerusalem, hecha por Vespasiano y Tito evokes the popular legends that date back through a myriad of versions to the twelfth century, and which, as I have mentioned, were printed in Spain and Portugal in the 1490s. Although more scholarly, Cromberger moves Palencia's version into the ideological ambit of popular tradition, loosening its ties to the historical circumstances and readerly co-existence that produced it.

Open Access This article is distributed under the terms of the Creative Commons Attribution 4.0 International License (http://creativecommons.org/licenses/by/4.0/), which permits unrestricted use, distribution, and reproduction in any medium, provided you give appropriate credit to the original author(s) and the source, provide a link to the Creative Commons license, and indicate if changes were made.

\footnotetext{
50 Josepho de belo judaico: los siete libros que el autentico hystoriador Flauio Josepho escriuio de la guerra q[ue] tuuiero[n] los iudios co[n] los romanos, y la destruycio[n] de Jerusalem, hecha por Vespasia[n]o y Tito, Seville, Jacobo Cromberger, 1532 (repr. 1536).
} 